\title{
CHALLENGES TO THE MULTIMODAL TRANSPORT NETWORKS BASED ON SUSTAINABLE GROWTH IN THE VOLUME OF CONTAINERIZED CARGOES
}

\author{
Valentina Grancharova \\ Nikola Vaptsarov Naval Academy (Bulgaria)
}

\begin{abstract}
Globalization is a significant factor for optimization of the existing transport chains. It is a major power for sustainable development of containerized transport, the relevant transport infrastructure and terminal equipment.

The development of seaports and inland waterway connections became important part in global supply chain. The transportation models which are using multimodal transport service consist from maritime, port and hinterland parts. Choosing the appropriate strategy allows the shipping companies to reduce the transport cost and helps them to be more competitive on the cargo market. This article aims to identify the challenges and prospects for development of multimodal transport operations with containerized cargoes using of system approach to the each subsystems of the multimodal transport chain. To achieve the scope of the paper, research has been done on the global effects that big shipping companies contribute to the final transport cost; to the organization in container terminals and further influence on the local terminal operators; to the improvement of port infrastructure, including the number of offered services and implementation of innovations for increasing terminal efficiency. As a result, the main parameters for evaluation of the importance of one container terminal in the supply chain are defined.
\end{abstract}

Keywords: port; port terminal; container; multimodal transport

\section{Introduction}

The continuous growth of container trade in recent decades is a clear example for the development of world economy. Containers ensure easy modal transfer of cargo and allow significantly reducing the production cost with relocation of many factories far from the customers in countries with low cost workforce, where for example semi-finished products can be assembled. One of the main advantages of container transport is the fact that it offers door-to-door service without the need for additional repackaging of the goods and breaking up the parcel.

Despite the fluctuations in world trade as a result of economic cycles, the evolution of the political processes remains the trend of sustained growth of trade 
flows (Yotsov 2019). A large container shipping alliances influences the already created transport chains worldwide.

Nowadays, the container transport system is a considerable part of the world trade and a preferred method for distribution and delivery of a variety of goods to the customers even in distant places.

\section{Paper layout}

The carriage of goods in standard freight containers often involves the combined use of several modes of transport and is the reason for the creation of multimodal transport networks. The shipping companies use the power of multimodal transport networks and integrated logistics to offer lower transportation cost and additional services such as tracking and tracing of the transportation process, storage and warehouse management, distribution, etc. which promotes a further increase in the volume of containerized cargoes, integration of new automated technology and construction of larger container vessels. Big sized container ships reduce significantly the final cost of the service but they have additional requirements, regarding port water area and shore facilities (crane size and crane productivity). Therefore the containers from latest generations can visit only in a few large ports in the world like these in Shanghai, Singapore, Rotterdam, Norfolk, Los Angeles, etc. Multimodal transport service offers secure carriage; it saves time for transshipment and minimizes the possibility for damage and loss of cargoes (Table. 1). The organization of the whole transport process in the multimodal transport chain, including the burden for preparing of time schedule, cargo documentation and all other formalities, is the obligation of the container operator.

Table 1. Advantages of multimodal transport services

\begin{tabular}{|l|}
\hline \multicolumn{1}{|c|}{ Multimodal Transport Service } \\
\hline - Transportation \\
- Route choice \\
- International transport connections \\
- Alternative for using terminals \\
\hline - Facilities \\
\hline - Terminal recommendation \\
- Warehouse management \\
\hline - Inventory \\
- Service of leased containers \\
- Cargo packing and handling \\
- Container leasing \\
\hline - Communication and information \\
\hline - Consolidated service \\
- Fast exchange of cargo documentation \\
- Electronic data exchange \\
\hline
\end{tabular}


- Trace and tracking of whole transportation process

- Real communication system based on RFID, OCR, GPS and GSM technologies

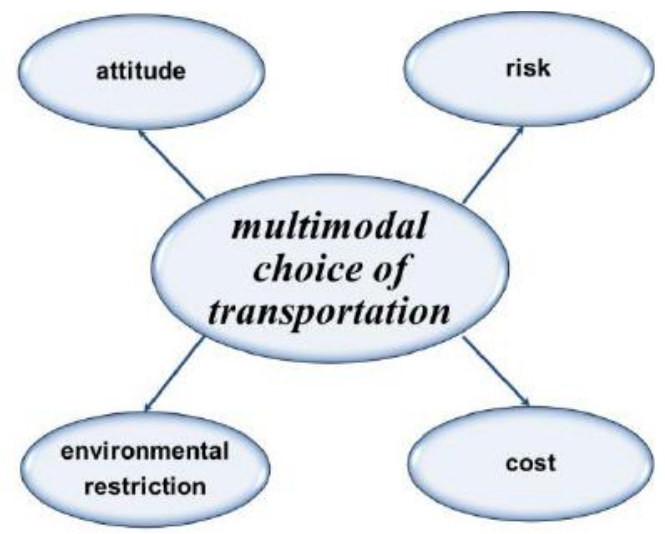

Figure 1. Factors related to choosing multimodal transportation

For instance, a railway carriage of cargo has a slight impact on the environment in contrast to road transportation. It is more reliable and is preferred as convenient mode of multimodal cargo transportation in case of long land distance, especially in USA, where the railway network has good coverage and allows a large volume of containerized cargo to be delivered in ports from inland logistic parks and terminals. In some large ports, such as the Ports of New York and New Jersey, the cargo transportation by such conventional trains is normal and fastest way for connection between remote terminals.

The service called "combined railway transportation" connects different parts of Europe and offers carriage of cargo, stowed in standardized ISO freight containers, semi-trailers or swap bodies, among ports and inland terminals, located over long distances. Due to lower cost efficiency at short distances despite favorable conditions, such as secure and timely transportation, rail transportation is still viewed negatively by multimodal companies. Risk of disturbances, caused by delays due to congestion and accidents on the road and environmental restrictions, can be considered as turning point and contribute to promote positive attitude towards rail transportation.

A negative aspect of road transportation is noise and the emission of exhaust gases in the atmosphere. It is used often at both ends of one multimodal transport chain for quick pick-up and for delivery from/to terminals within a short distance. Despite of the higher level of flexibility and accessibility of road transportation, the strategy of many countries in Europe is connected with reduced appliance of 
road networks and refers to waterways and rail transport as more environmentally friendly options for cargo carriage, not only in single mode transportation but also for multimodal transportation. The results from many studies show that combining different modes of transport in one multimodal supply chain is effective in case of distances above $500 \mathrm{~km}$. For distances below $250 \mathrm{~km}$, road transportation is more competitive on the market than rail and inland transport, especially in the vicinity of a port with its high speed delivery (Fig. 2).

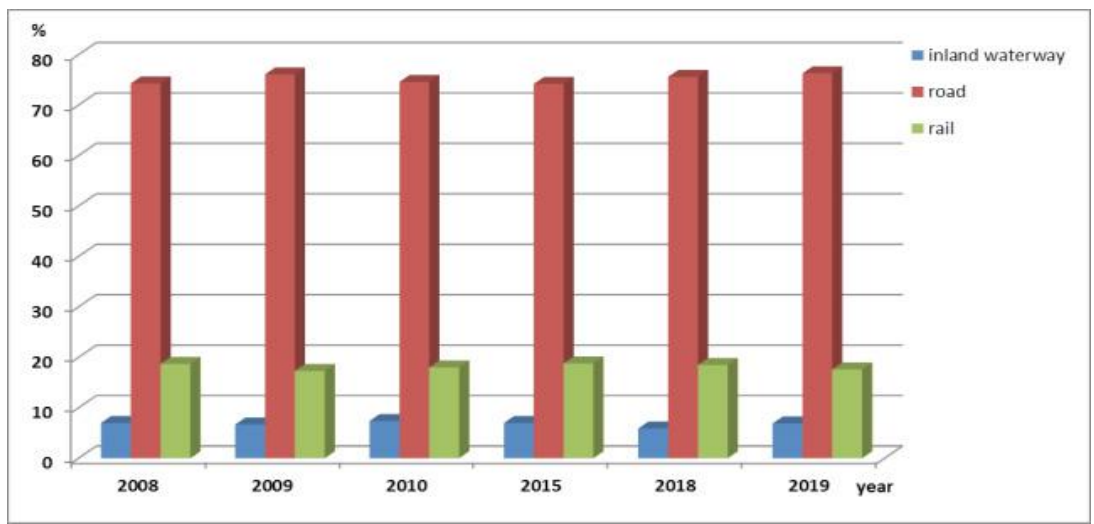

Figure 2. Modal split of freight transport in EU countries

Inland waterways as option for multimodal transportation need additional expenses for terminal handling. The lack of draught and availability of navigable waterways and bridge clearance are some of the obstacles for reaching a bigger share in transport traffic in Europe, especially in multimodal transport chains, including deep sea transportation. One typical multimodal transport chain is shown on Figure 3.

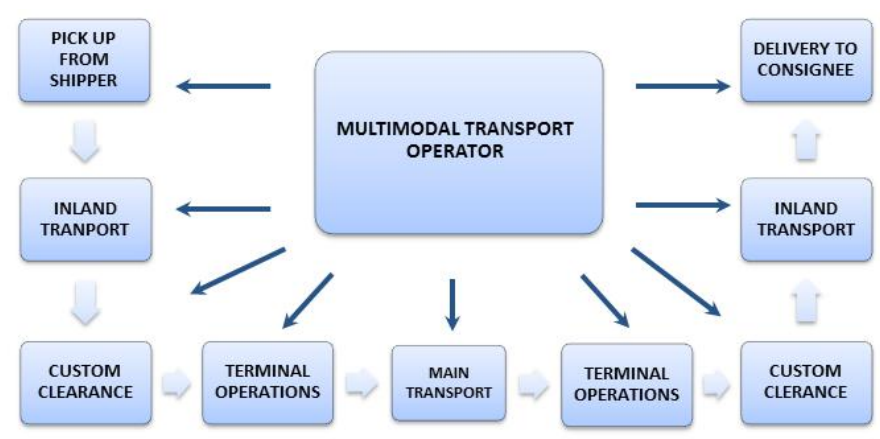

Figure 3. Scheme of multimodal transport chain 
The main priorities of the multimodal transport concept over using of single transport are: proper combination of different modes for cargo carriage, possibility for international transport operation; and the whole responsibility is left in hands of one single operator. Offering of favorable freight rates enables multimodal transport operator companies to be more competitive on the market.

The necessity for developing of sound business relationships with stakeholders as intervening parties is deemed to be of vital importance that helps reach the desired quality of service. Multimodal transport operators use three approaches when composing the itinerary of container flow at deep sea routes:

- Liner service in defined ports in different continents - one of these ports is chosen for central port (hub) in which the regrouping of containers is performed. The advantage is better use of container ship load capacity, because container slots might be used many times during one voyage.

- Round service between continents - these lines cover trade directions around the world in one. The containers can be carried for example in east or west direction or in both directions. This approach gives the possibility of changing the number and order of port calls, as well as adding and bringing out of ports from the container line.

- Regular service of the "end-to-end" type - Container vessels serve a container line between two continents (for example between Europe and Asia). The disadvantage is irregularly container flow between a wide range of ports located in both directions.

For international carriage of containerized cargo the shipping lines need implementation of integrated system approach that emphasizes technical requirements in the different stages of cargo movement. Depending on their specifics, multimodal transport networks can be divided into the following subsystems: carriage of goods inland, from inland to port terminal and between ports. Creating multimodal transport chains and choosing modes for transportation is determined by established organizational management and by the available equipment of each subsystem. The main goal is ensuring good cooperation between different parties involved in cargo transportation, fast exchange of cargo documents and receiving accurate information, concerning the current status of the goods.

The multimodal transportation of containerized goods generates considerable profits for shippers such as providing better cost control, minimizing damages and losses during transshipment between modes of transportation and loss of time for terminal operations, giving additional competitive power and flexibility to respond to unexpected changes in global market. The trend in the last decade is that container shipping companies strive to embrace the whole multimodal transportation process and provide end-to-end logistics service of cargo by land and sea. Expanding the number of offered services and including additional operations at port terminals and inland logistics allows them to reduce significantly the cost and to give an attractive price for the multimodal transportation. 
Most carriers strive to create their own feeder services and to have hinterland transport operators. These allow carriers to control information concerning cargo flow and to play on the market also as freight forwarders. They have the possibility to choose the mode of inland and/or ocean transport, port and terminals and all other related services. Clients receive a complete solution regarding cargo carriage that is not always the best possible, and they chose it because the responsibility regarding the whole transportation process belongs to one company. Besides, they are limited in many cases to use a specific information system and any refusal could cause additional expenses for shippers.

The Linear Supply Connectivity Index (LSCI) reports how well the countries are connected in the world maritime network. It is compiled by UNCTAD and is based on five components of the maritime transport: number of ships, load capacity in TEU, maximal vessels' sizes, number of port calls and number of companies owning containers in the relevant country. The implementation of direct container lines between two ports is not always possible, because not all countries have large ports and direct access to the sea. Freight forwarders prefer to transport containers directly from port to port without intermediate transshipment during voyage in order to reduce the risk of unexpected cargo delays and further claims. Shippers in some of the developed European countries, such as Germany, France, Spain, Italy, the Netherlands, perform transportation without transshipment at about 50\% of their deliveries to the countries located in rest on the continent. The countries situated on the periphery of Europe need at least one intermediate transshipment.

Nowadays terminal operations worldwide are concentrated in the hands of 21 global players, most of them connected with large container shipping companies, and incorporated in three alliances. According to UNCTAD, the total amount of containers handled worldwide ports in 2019 is 811.2 billion TEUs. At the same time, the volume of containers handled by global alliances and their terminal operators has increased by $3.1 \%$ and reached 645.8 billion TEUs. Their influence on the market increases constantly and in 2018 reached $80 \%$ share of the market.

The implementation of vertical integration from carriers means higher service rate and smaller variance. It must be in full compliance with potential losses caused by lower competition and the presence of external negative effects. Vertical integration distorts competition in other segments, for example between terminal operators and other non-integrated service providers.

Terminal operators also create international consolidations but they do not have the same power as the established three global alliances of carriers. Furthermore, the ten largest carriers have $80 \%$ market share among carriers and the ten largest terminal operators have only $40 \%$ presence in market share of terminal operators. Each alliance regulates container flow and redirects them from one port to another that has less calls from companies outside them (Evangelista et al. 1999; Panayides et al. 2011). 
The influence of alliances and their terminal operators over the first three largest European container ports in Rotterdam, Antwerp and Hamburg in 2016 is shown on Figure 4. At that time, the global alliances had under direct control 21 container terminals in Europe located in the West Mediterranean and North-West Europe, with total capacity of 20 million TEUs. In comparison, in the same year the top EU ports (Rotterdam, Antwerp and Hamburg) handled $36.3 \%$ of the containers transported from/to main EU ports.

During the last decade, the volume of containers (loaded and empty) handled in main EU ports has grown and in 2019 reached 96,572 million TEUs (Fig. 5) $)^{1,2), 3), 4)}$. Of the containers handled in EU countries, $70 \%$ belong to five countries. 5 . The

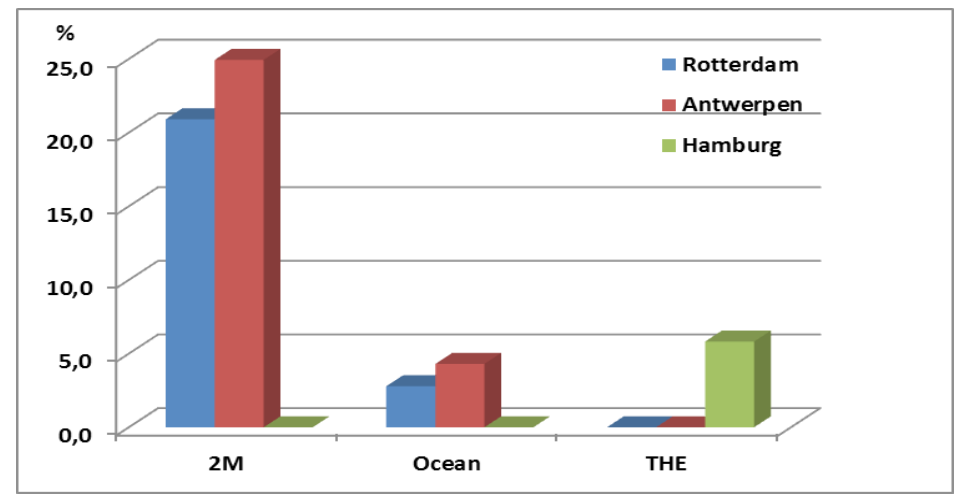

Figure 4. Influence of alliances and their terminal operators in the top three EU container ports in 2016

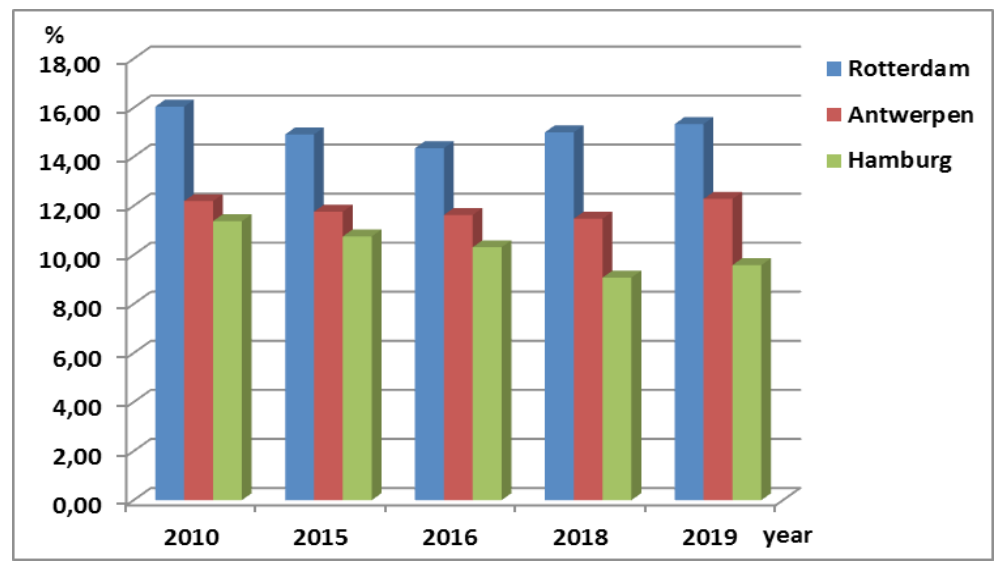

Figure 5. Percentage of containers handled in the three main EU ports 
largest volume is is generated by Spain (18\%), Germany (15.6\%), the Netherlands $(14.4 \%)$, Belgium $(12,6 \%)$ and Italy $(11.5 \%)$. The amount of empty containers in the port of Genoa is the lowest ( $2 \%$ ). In contrast, the share of empty containers in the port of Felixstowe has grown to 32\% or a total of 5.2\% for EU ports. Reaching the balance of empty containers worldwide is another challenge for multimodal transport. In 2019, the ports of Rotterdam, Antwerp and Hamburg increased the percentage of their container flow to $37.2 \%$. One of the reasons for the enhancement of container throughput in the port of Hamburg with $6.1 \%$ is defining the container terminal as hub for THE Alliance.

The container flow worldwide depends on the chosen economic strategy of the shipping companies and whether these companies use forwarding agents for the provision of certain services. The freight containers arrive in hubs for further ocean transportation by sea (from small coastal port and inland terminals with feeders or barges), by land (using railway or road network) and by air. Container terminals in smaller coastal or river ports handle small container vessels with load capacity up to 2500 TEUs. Whether one port will be included in a container line or not depends on a number of factors, such as current and expected intensity of cargo flow in containers in the already established logistics network, political stability in the region, etc. Many studies show that multimodal transport chains are influenced considerably by the current political situation. On the other hand, logistic operations have direct influence over the development of a region or country. The rapid development of one region is often a result of an increase in the number of ports included in a container line.

The organization at port terminals depends on container shipping companies who have direct control. When the complex system theory (system approach) is applied and the maritime transportation infrastructures are counted as a part of maritime critical infrastructures, the security analysis in the framework of the whole system will be spread over its part - the transportation system (Mednikarov et al. 2018).

Whether one port or terminal will be chosen as a hub by a shipping company or not is a matter of company policy and market strategy. For example, company "MSC" uses the container terminal in port of Antwerp as hub for Europe, but for company "Maersk" the port is one of their feeder ports. The terminal in Algeciras is the main European hub for "Maersk", but it is relatively insignificant in the "MSC" network.

The establishment of large container shipping alliances influences the whole transport sector worldwide and the already created maritime transport chains. They give carriers a chance to reduce vastly their transport cost per unit by operating large container vessels. The cooperation between companies in an alliance makes it possible to reduce service frequencies, flexibility for changing the number and rotation of ports in a container line, less direct port-to-port in one line that leads 
to enhancement of total transit time, and, as a consequence, to higher buffer cost and uncertainty for shippers. Large ports operate with one or more alliances. The risk for losing their shipping companies as clients provides alliances with huge leverage over ports. They are constrained to reduce rates and invest in additional port infrastructure allowing fast container cargo handling. On the other hand, the buying power of large carriers can create at ports unfair competition between terminal operators and between other port service providers that is further reflected in decreased rates of return on investment in the port area. As a result, smaller container ports and independent terminal operators disappear because they are already not competitive on the market.

Another negative effect is the pressure of big players for publicly funded innovation in port infrastructure allowing the servicing of mega-large container vessels. In most cases, these investments are not economically justified. Terminals controlled by carriers contribute to the rise of existing competition. Investment in such terminals could also be seen as a way to limit price whereby operation costs of potential clients is increased to a level that makes entry no longer profitable. Often these terminals are constrained to give special service price or discounts to defined carriers, which are at lower level than the alternative social costs. Other carriers have to wait longer for handling or to pay extra expenses that make them uncompetitive.

Port congestion is connected also with securing berthing place for a vessel. Such congestion occurs at least once a week in major European ports. This affects the vessel's schedule and leads to unpredicted delay and additional costs. According to Dynamar, feeder vessels have often low priority by arranging place of berth in case that feeder operator has agreement clause FIO with carriers, i.e. they are not direct clients of the terminal and carrier pays expenses for loading and unloading of feeder ${ }^{6,7}$. It goes without saying that large shipping companies are able to put pressure on the terminal schedules. This problem is serious especially in tidal ports that have short berthing windows. Shippers are constrained to load the container which is rolled to the next vessel in schedule and to pay additional charges at port and to clients for the delay.

Avoiding port congestion also requires collaboration and improvement of communication between the parties in multimodal transport chains (carriers, shippers and freight forwarders). It is necessary to reach good coordination in the following stages: vessel arrival and berth, performance of cargo handling operation and storage at container yard, transshipment from/to port to/from inland transport means such as trains, load vehicles or barges, delivery or pick up cargo to/from port.

Optimization in terminal is connected to minimizing the time for terminal movement and additional restacking in yard area. Digitalization in transport sector also makes it possible for data and information to be exchanges between stakeholders and for more effective services to be offered to their customers. Analysis 
and assessment of the market situation helps them take appropriate decisions and changes their company strategy for improving their competitive power on the market. Optical character recognition (OCR) technology is applied successfully at an inland terminal in Northwestern Europe for easy recognition of text in cargo documents. Another solution in this direction is the application of electronic CMR and block-chain technology, which is often integrated in terminal operating systems (TOS) and manages processes at large ports, especially the performance of customs clearance for international container flows. Platforms tracking the shipping process can be deemed as part of the technical cooperation between shipping companies and help ensure better service. The companies "Maersk" and "IBM" promulgated in 2018 the creation of a platform that will cover the whole transportation process. It will connect various numbers of stakeholders, including shippers, terminal operators and national authorities. Other major companies such as "CMA CGM" and "HMM" and "SM Line" have made investments in the digitalization of cargo flow information exchange.

The implementation of a unified communication platform between container shipping companies in one alliance could distort fair competition and put additional pressure on small companies. In Northern Europe, the market share of feeder container transport in 2018 was 68\%, and in Southern Europe - 59\%. Therefore, the state policy of each country should be directed at reducing the negative impact of alliances on the market and performing straight control on the influence of liner shipping alliances over terminal operators and local transport companies.

\section{Conclusions}

The multimodal transport system should be capable of integrating all parties' stages between shippers, consignees and multimodal operator's responsibility. Reducing transport costs and transit time is very important for economic growth and the development of trade in the regions and for decision making for future investment in the transport infrastructure and terminal equipment.

The inclusion of one container terminal in multimodal transport chain takes into consideration the evaluation of: stowage planning, berthing activities, capacity of terminal equipment, time for loading or discharge, capacity of storage yard, possibility for transfer to inland transport.

The competitiveness of terminals is in strong relation with local and state policies, the inland connections with ports and the process of economic development in the region. The potential risk of carriers preferring another port of call limits the benefits for terminal operators. Common reasons include: weaknesses in operating systems and opportunities for unauthorized access to critical infrastructure management computer networks (Nikolov 2019).

Alliances lead to the disappearance of smaller container ports and independent terminal operators. As a result, in 2019 on the two main trade lanes with Asia and 
Europe, only six ports in North America receive calls from the three alliances. In Asia on the same trade line, they are nine, and in Europe - five.

The introduction of digital solutions for cargo document flow is another challenge that helps improve the connectivity and transparency of the performed processes at different stages of the multimodal transport chain. It reduces the inefficiencies of cargo flow through better container utilization, evasion of delays during transportation and congestion at terminals, decrease of $\mathrm{CO}_{2}$ emissions and preserves the product quality during the carriage and in the storage yard.

\section{NOTES}

1. UNCTAD. The Review of Maritime Transport 2011[online]. Geneva: United Nations Publication, 2011. ISBN 978-92-1-112841-3. Available from: https:// unctad.org/en/PublicationsLibrary/rmt2011_en.pdf

2. UNCTAD. The Review of Maritime Transport 2015 [online]. Geneva: United Nations Publication, 2015. ISBN 978-92-1-112892-5. Available from: ttps:// unctad.org/en/PublicationsLibrary/rmt2015_en.pdf

3. UNCTAD. The Review of Maritime Transport 2018 [online]. Geneva: United Nations Publication, 2018. ISBN 978-92-1-112928-1. Available from: https:// unctad.org/en/PublicationsLibrary/rmt2018_en.pdf

4. UNCTAD. The Review of Maritime Transport 2019 [online]. Geneva: United Nations Publication, 2020. ISBN 978-92-1-112993-9. Available from: https:// unctad.org/en/PublicationsLibrary/rmt2020_en.pdf

5. DREWRY.: Global Container Terminal Operators. Annual Review and Forecast. Annual Report 2017 [online]. London: Drewry Maritime Research, 2017. Available from: https://drewry.co.uk/maritime-research-products

6. American Journal Of Transportation: Statement of the WSC on the Issuance of the International Transport Forum's Report on The Impact of Alliances in Container Shipping [online]. 2018. [Accessed 11 March 2019]. Available from:https://www.ajot.com/news/statement-of-the-wsc-on-the-issuance-of-theinternational-transport-forums-report-on-the-impact-of-alliances-in-containershipping

7. DYNAMAR: Transhipment and Feedering 2018: Trades and Operators - Ships and Hubs [online]. 2018. [Accessed 11 March 2019]. Available from: https:// dynamar.com/publications/195

\section{REFERENCES}

Evangelista, P. \& Morvillo, A., 1999. Alliances in Liner Shipping: an Instrument to Gain Operational Efficiency or Supply Chain Integration? International Journal of Logistics Research and Applications (2), 21 - 38. ISSN: 1367-5567. 
Mednikarov, B., Dimitrov, N., Vasilev, V., 2018. Security analysis of the National Maritime Transportation System as part of National Critical Infrastructures. In: $A G A$ 2018, Barcelona: International Center for Numerical Methods in Engineering, 344-351. ISBN: 978-84-947311-7-4.

Nikolov, Zh., 2019. Maritime critical infrastructure cybersecurity aspects overview [online]. Izvestia SU-Varna, Section "Marine sciences", 3 - 6. ISSN: 1314-3379. Available from: http://www.su-varna.org/ izdanij/2019/ MN_Proceedings_2019.pdf

Panayides, P. \& R. Wiedmer, 2011. Strategic Alliances in Container Liner Shipping. Research in Transportation Economics 32, 25 - 38. ISSN: 0739-8859.

Yotsov, I., 2019. The Role of Short Sea Shipping Concept in Black Sea Region as a Connection between Eurasian Transport Systems [online]. Journal of Traffic and Transportation Engineering 7, 246-263 [Accessed 21 February 2021]. doi: 10.17265/2328-2142/2019.06.002

$\triangle$ Valentina Grancharova

https://orcid.org/0000-0002-0564-8258

Nikola Vaptsarov Naval Academy

Varna, Bulgaria

E-mail: v.grancharova@nvna.eu 